\title{
The first report of ants (Formicidae: Hymenoptera) in salt marshes and salt pans in central parts of Iran
}

\author{
MOHAMMAD REZA MOHSENI ${ }^{1, \boldsymbol{v}}$, SHAHROKH PASHAEI RAD ${ }^{2, ~}$, \\ ${ }^{1}$ Department of Animal Science, Science and Research Branch, Islamic Azad University, Tehran, Iran. "email: mrmohseni1992@ gmail.com \\ ${ }^{2}$ Associate Professor of Animal Biosystematics, Faculty of Life Science \& Biotechnology, Department of Animal Science \& Biotechnology, Shahid \\ Beheshti University G.C., Tehran, Iran. "vemail: sp2191@gmail.com)
}

Manuscript received: 29 June 2019. Revision accepted: 17 August 2019.

\begin{abstract}
Mohseni MR, Pashaei Rad SP. 2019. The first report of ants (Formicidae: Hymenoptera) in salt marshes and salt pans in central parts of Iran. Biodiversitas 20: 2536-2546. This study attempts to introduce the ant species of salt marshes and salt pans in central parts of Iran. Investigating the effects of ecological factors on the ant species diversity and distribution is the other main aim of this study. The study was conducted in salt marshes and salt pans in central parts of Iran. As many as 121 specimens of ants were collected by trapping and hand during spring, summer and autumn from 2017 to 2019. The vegetation, physical and chemical parameters of soil such as salinity, $\mathrm{pH}$ and other factors were investigated. Messor ebeninus (Santschi, 1927), Monomorium indicum (Forel, 1902), Monomorium rimae n. sp. (Collingwood \& Agosti 1996), Tetramorium sp. (Mayr, 1855), Cataglyphis niger (André, 1881), Cataglyphis bellicosus (Karavaiv, 1924), Cataglyphis setipes (Forel, 1894), Cataglyphis lividus (André, 1881) and Lepisiota dolabellae (Forel, 1911) belong to two subfamilies of Myrmicinae and Formicinae were identified. Darband Shoor Mountain had the highest ant diversity with five species in which the area had the highest vegetation density and the lowest salinity of soil (72.14 ds/m), whereas Salt Lake that had no vegetation and the highest salinity of soil $(153.15 \mathrm{ds} / \mathrm{m})$ had only one species, which is $C$. lividus, indicating a high adaptation of this species to salt pans and salt marshes. C. lividus was the dominant species in all the stations except in Darband Shoor Mountain. To our knowledge, all species were reported for the first time from salt marshes and salt pans in the central parts of Iran.
\end{abstract}

Keywords: Ant, salt marsh, salt pan, soil, vegetation

\section{INTRODUCTION}

Ants with more than 12,000 species, play a very crucial role in earth's ecosystem and are known as soil engineers (Ward 2007; Sanders and Van Veen 2011; Griffiths et al. 2017).

Ants' biodiversity and their role in nature are more significant than those of humans (Folgarait 1998; Wardle et al. 2011; Luke et al. 2014; Houadria et al. 2016 and Griffiths et al. 2017). Investigating these impacts is of overriding importance in the development of medical sciences, agriculture, strategic studies, etc. Therefore, it is essential to identify the species living at each station based on its biological and ecological conditions. (Clark et al. 2011; Cardoso and Schoereder 2014; Belchior et al. 2016). Considering a few investigations and the need to complete the ants' fauna, especially in special biotic zones, the present study aims to collect and identify existing species in salt pan habitats and salt marshes of the central parts of Iran with their distinctive vegetation.

Several studies have been conducted on ants' ecosystem, distribution and biodiversity, especially in different parts of the world, including Davis and Gray's (1966) studies, McCoy and Rey (1987), Schultz (2000), Agosti and Johnson (2003), Palomo et al. (2003), Jones (2008), Rabeling et al. (2008), Jilkova et al. (2012), Loken and Oliver (2016) and Dahmen et al. (2017) and etcetera. Ants exist on all continents except Antarctica and only a few major islands such as Greenland, Iceland, parts of Polynesia and the Hawaiian Islands lacking native species (Jones 2008 and Ward 2007). Ants can eat vegetarian food directly or indirectly, as well as being able to hunt and eat because they use a wide range of foods. They have been able to spread and expanded in many lands. Among animals, ants make up $15 \%$ to $20 \%$ of different habitats and $25 \%$ of the tropics (Schultz 2000).

Generally speaking, salt ecosystems are not regarded as appropriate environments for the distribution and biodiversity of animal species, but adaptation of each species to these types of habitats due to less competitiveness and more access to food sources, can bring about a rapid growth and distribution in the future (Loken and Oliver 2016; Foster and Treherne 1976). Special conditions of these types of ecosystems such as specific physical and chemical parameters of the soil like high salt levels, the absence of many plant species incompatible with these unique regions and climates of these ecosystems impose restrictions on the presence of many species of animals. This sort of limitation is much more pronounced in some habitats. For example, salt marsh and salt pan ecosystems in desert regions with scorching and dry climates and very poor vegetation would be much more understandable to biological constraints (Mohseni 2018). Salt ecosystem inhabitants regularly develop particular adaptations and behaviors to endure alternating dry conditions (Loken and Oliver 2016). Some organisms of 
salt marshes tolerate inundation by beginning a hypoxic coma when immersed, for instance (Pétillon et al. 2009). If compromised, due to considerable decreasing of biological competition, these species will have a much higher chance of survival (Foster and Treherne 1976) as only a limited number of organisms can tolerate these conditions. Compatible species are rewarded with distinct availability to a trustworthy resource.

In Iran, studies and researches are dated back into two main periods: the first period was during one third of the $20^{\text {th }}$ century and carried out by Forel (1904) on male dimorphism in ants and some other myrmecological records, Emery (1906) on critical review of the Palearctic species of the genus Myrmecocystus and Menozzi (1927) on the study of the Persian Gulf (Entry nr. 12) Formicidae (Hym.), while the second period began from 1990 to now and included the studies of Ardeh (1994) on investigating Characteristics and behavioral characteristics of the ants in Karaj city, Iran, Paknia et al. (2010) and reporting new records of ants (Hymenoptera: Formicidae) from Iran, Pashaei Rad et al. (2018) on further records of ants (Hymenoptera: Formicidae) from Iran and Mohseni (2018) on identification and biodiversity of Ants (Formicidae: Hymenoptera) in central parts of Iran.

The few investigations draw our attention to fill the gap of knowledge about ants' ecosystem, distribution and biodiversity, especially in specific biotic zones. The present study aims to collect and identify existing ant species in salt pan habitats and salt marshes of the central parts of Iran with their special vegetation. To our knowledge, this is the first time study on such theme in the region.

\section{MATERIALS AND METHODS}

\section{Stations and sampling methods}

We divided the study areas in salt marshes and salt pans in central part of Iran (Figure 1) into five stations, namely the central area of Salt Lake, the margins/borders of Salt Lake, Sadr Abad Historical Caravanserai, Qomrood salt pans and Darband Shoor Mountain (Figure 1, Figure 2).

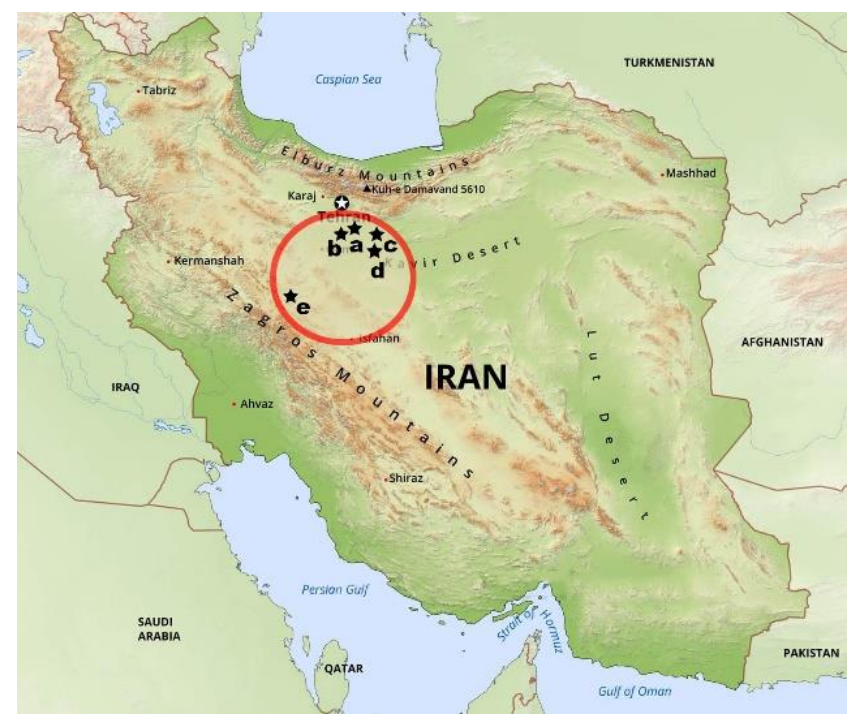

Figure 1. Map of the studied areas in salt pans and salt marshes in central Iran
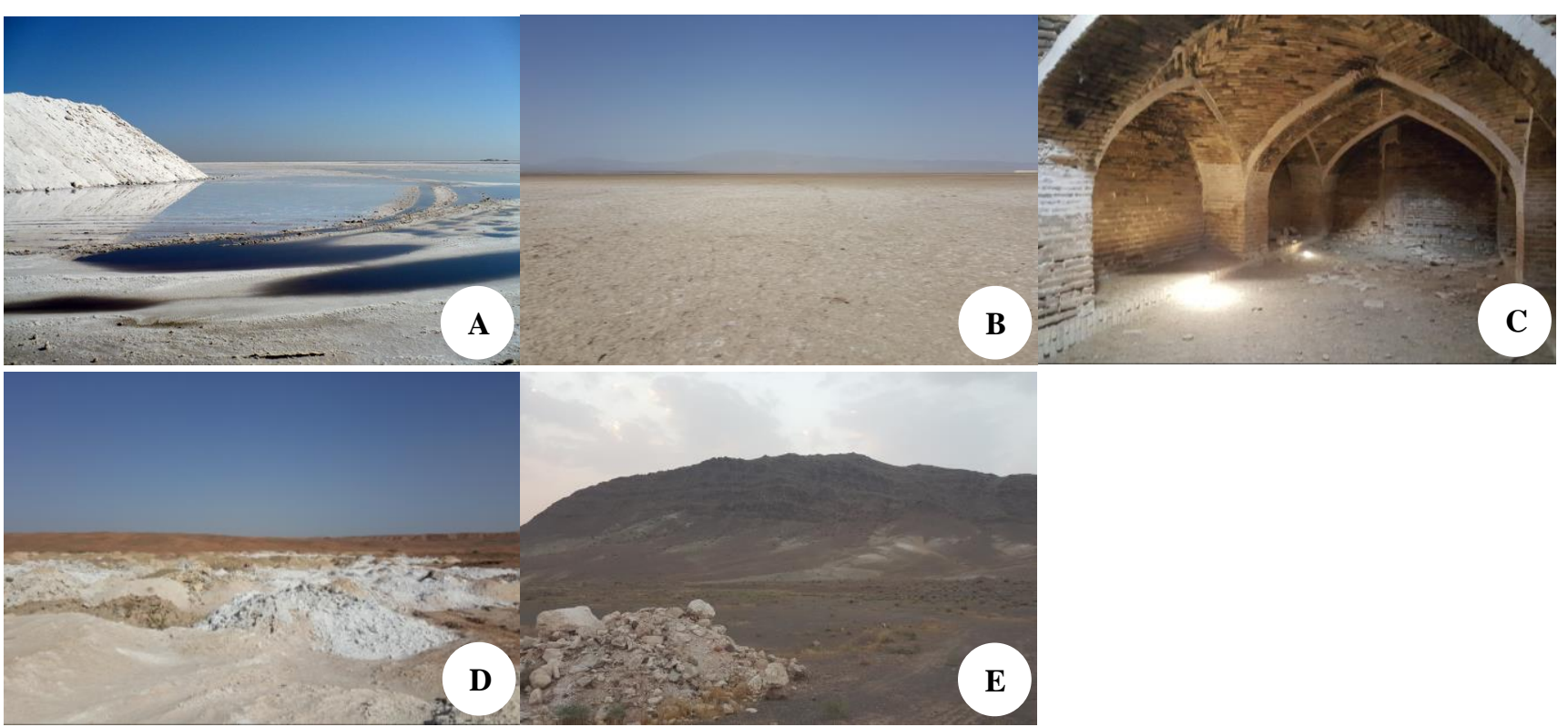

Figure 2. Research stations in central part of Iran: A. the central area of Salt Lake, B. the margins/border of Salt Lake, C. Sadr Abad Historical Caravanserai, D. Qomrood salt pans, and E. Darband Shoor Mountain 
Table 1. Information on sampling stations and methodology

\begin{tabular}{|c|c|c|c|c|c|c|c|}
\hline Locality name & $\begin{array}{l}\text { Lat }(\mathbf{N}) \text {; } \\
\text { Lon }(\mathbf{E})\end{array}$ & Habitat & $\begin{array}{c}\text { Temp. in } \\
\text { different } \\
\text { seasons } \\
\left({ }^{\circ} \mathrm{C}\right)\end{array}$ & $\begin{array}{c}\text { Humidity } \\
\text { in different } \\
\text { seasons } \\
(\%)\end{array}$ & $\begin{array}{l}\text { Elevation } \\
\text { (m) }\end{array}$ & $\begin{array}{l}\text { Date collected in } \\
\text { different seasons }\end{array}$ & Method \\
\hline $\begin{array}{l}\text { Salt lake (central } \\
\text { area) }\end{array}$ & $\begin{array}{l}34^{\circ} 58^{\prime} 03.4^{\prime \prime} \mathrm{N} \\
50^{\circ} 54^{\prime} 05.8^{\prime \prime} \mathrm{E}\end{array}$ & $\begin{array}{l}\text { On the center } \\
\text { of salt marsh }\end{array}$ & $32-50{ }^{\circ} \mathrm{C}$ & $7-9 \%$ & $804 \mathrm{~m}$ & $\begin{array}{l}\text { A: } 10 \text { AM, } 7 \text { PM } \\
\text { M: } 8 \text { AM, } 5 \text { PM } \\
\text { J: } 9 \text { AM, } 6 \text { PM } \\
\text { S: } 10 \text { AM, 6:30 PM } \\
\text { O: } 8 \text { AM, 5:15 PM }\end{array}$ & Pitfall \\
\hline $\begin{array}{l}\text { Salt lake (marginal } \\
\text { area) }\end{array}$ & $\begin{array}{l}34^{\circ} 57^{\prime} 45.1^{\prime \prime} \mathrm{N} \\
50^{\circ} 53^{\prime} 37.0^{\prime \prime} \mathrm{E}\end{array}$ & $\begin{array}{l}\text { Beside the salt } \\
\text { marsh }\end{array}$ & $34-55^{\circ} \mathrm{C}$ & $7-8 \%$ & $809 \mathrm{~m}$ & $\begin{array}{l}\text { A: 10:30 AM, } 6 \text { PM } \\
\text { M: 8:50 AM, } 5 \text { PM } \\
\text { J: 9:30 AM, } 6 \text { PM } \\
\text { S: 10:40 AM, } 7 \text { PM } \\
\text { O: } 9 \text { AM, 6:00 PM }\end{array}$ & $\begin{array}{l}\text { Hand } \\
\text { collection }\end{array}$ \\
\hline $\begin{array}{l}\text { Sadr Abad Historical } \\
\text { Caravanserai }\end{array}$ & $\begin{array}{l}34^{\circ} 53^{\prime} 05.3^{\prime \prime} \mathrm{N} \\
51^{\circ} 04^{\prime} 41.1^{\prime \prime} \mathrm{E}\end{array}$ & On salty soils & $33-45^{\circ} \mathrm{C}$ & $6-9 \%$ & $806 \mathrm{~m}$ & $\begin{array}{l}\text { A: } 11: 15 \text { AM, } 6 \text { PM } \\
\text { M: } 10 \text { AM, 7:30 PM } \\
\text { J: 10:30 AM, 6 PM } \\
\text { S: } 8 \text { AM, 6:20 PM } \\
\text { O: } 9 \text { AM, 6:00 PM }\end{array}$ & $\begin{array}{l}\text { Hand } \\
\text { collection }\end{array}$ \\
\hline Qomrood salt pans & $\begin{array}{l}34^{\circ} 43^{\prime} 33.3^{\prime \prime N} \\
51^{\circ} 03^{\prime} 57.7^{\prime \prime} \mathrm{E}\end{array}$ & $\begin{array}{l}\text { On salt fields } \\
\text { beside shrubs }\end{array}$ & $29-46{ }^{\circ} \mathrm{C}$ & $11-15 \%$ & $844 \mathrm{~m}$ & $\begin{array}{l}\text { A: } 9 \text { AM, } 7 \text { PM } \\
\text { M: } 8: 40 \text { AM, } 5 \text { PM } \\
\text { J: } 10 \text { AM, } 6 \text { PM } \\
\text { S: } 10 \text { AM, 6 PM } \\
\text { O: } 8 \text { AM, 5:15 PM }\end{array}$ & Pitfall \\
\hline $\begin{array}{l}\text { Darband Shoor } \\
\text { Mountain }\end{array}$ & $\begin{array}{l}34^{\circ} 25^{\prime} 50.9^{\prime \prime} \mathrm{N} \\
50^{\circ} 38^{\prime} 46.9^{\prime \prime} \mathrm{E}\end{array}$ & $\begin{array}{l}\text { Beside salty } \\
\text { rocks }\end{array}$ & $30-40{ }^{\circ} \mathrm{C}$ & $13-16 \%$ & $1259 \mathrm{~m}$ & $\begin{array}{l}\text { A: 9:30 AM, } 6 \text { PM } \\
\text { M: 9:00 AM, } 5 \text { PM } \\
\text { J: 8:00 AM, } 7 \text { PM } \\
\text { S: 10:00 AM, 6 PM } \\
\text { O: 8 AM, 6:00 PM }\end{array}$ & $\begin{array}{l}\text { Hand } \\
\text { collection }\end{array}$ \\
\hline
\end{tabular}

Note: A: April, M: May, J: July, S: September, O: October

The geographical location and altitude are presented in Table 1. Each station was divided into three to five sections for sampling according to its extent. Sampling was done by the pitfall trapping method and also by hand at regular times and intervals in three seasons of spring, summer and autumn in the year of 2017-2019. Sampling was carried out twice per season for each station. To collect and record the abundance of visiting ants, stations were sampled once in the morning (8 AM-11:30 AM) and once in the afternoon (5 PM-8 PM), to ensure a better outcome of ant fauna.

Sampling faced special limitations, such as some extremely hot days in dry months (June, July, August, and September) and some rainy days in the wet month (October) due to unique climatic conditions of the salt marshes and salt pans in central parts of Iran. Air temperature across days varied between 30 to $55^{\circ} \mathrm{C}$ in dry months and between 29 to $45^{\circ} \mathrm{C}$ in rainy months.

Ants were observed on the salty soils, beside the shrubs, near the salt marshes, beside the salty rocks and exactly on the salt compounds in any position. Ant sampling used traps made of transparent containers covered with honey and sugar syrup, and was put near the colonies and wherever the presence of colonies was probable. The samplings were adjusted to the extent of sampling stations and the unique conditions of each station, such as the type of texture of the ground, the number of traps used (6-10 traps). Whilst the capture of specimens in pitfall traps mainly depends on the number of individuals in the gathering area, trap devising and trapping attempted for a given environment, which can also influence sampling progress. The optimum trap had to maximize catching and at the same time, minimize the risk of drying out. For this purpose, we used a metal roof that would limit direct sunlight on the trap, reducing vaporization rates as well as serving as a shelter during the hours of maximum solar radiation. Therefore, 6 to 10 traps were set in a regular network, separated $25 \mathrm{~m}$ from each other. In each trap, the total number of collected specimens and the species richness were quantified. In addition, collection by hand was done in colder parts of the day, for 2.5 to 3 hours per station on average. In areas where distribution and species richness were lower, manual sampling was used. It should be noted that due to sparse vegetation in the sampling areas, other methods such as vegetation beating was not efficient.

In order to evaluate the influence of environmental factors on the diversity and distribution of ant species, as well as side evaluations, all the plant species and the soil of each sampling station were collected.

\section{Identifying the specimens}

The collected specimens were taken to the Biosystematics Laboratory of Shahid Beheshti University in covered plastic test tubes containing 70\% alcohol and 
were identified through utilizing stereomicroscope and valid identification keys such as Collingwood (1985); Goulet and Hubert (1993); Bolton (1994); Collingwood and Agosti (1996); Radchenko (1998) and Hashimoto (2003) and by comparing the collected individuals with those specimens identified at the Hayk Mirzayans Insect Museum (HMIM) and the collection of African and Iranian Ants by Prof. Brian Taylor. Necessary photographs were taken by Dino Camera to capture the key features. All the species were reported for the first time from salt marshes and salt pans in the central parts of Iran and were approved by Prof. Brian Taylor in Royal Entomological Society of London, England.

\section{The diversity of vegetation}

Given the significance and effect of vegetation diversity in the frequency, biodiversity and the distribution of animal species, all plant species in each sampling station were collected and identified by Dr. Mehrabian, from the Department of Botany at Shahid Beheshti University of Tehran (Table 2). There were 89 specimens collected, 58 of which were naturally colonized by ants and the rest (31) were not. All plant species were less than $2 \mathrm{~m}$ tall (0.15-1.8 $\mathrm{m})$ and distributed in perfectly dry and salt pan areas with similar light availability (Figure 2). Plant specimens were inspected with high precision to evaluate the presence of ant specimens by carefully checking the leaves and shaking the stems of the plants. We observed, the Salt Marsh (marginal areas) and Salt Pan Areas had poor vegetation, however, during the rainy months especially April, May, and October There is a whole conceivable growth rate.

\section{Physical and chemical parameters of the soil}

The main purpose of collecting, examination and analyzing of the physical and chemical parameters of the soil at each sampling station was to evaluate the influence of soil factors on the population of the ant's communities and the variety of different ant species in salt marshes and salt pans.

Physical and chemical parameters of soil investigated at all the sampling stations included texture, clay, silt, sand, salinity Electrical conductivity $(\mathrm{Ec})$, acidity/alkalinity $(\mathrm{pH})$, total nitrogen content, organic carbon, absorbable phosphorus, absorbable potassium, magnesium, calcium, sodium and sodium absorption ratio (Table 3). Physical and chemical parameters of the soil in sampling stations were investigated by using Ec meter to measure salinity, $\mathrm{pH}$ meter to measure alkalinity, a flame photometer to measure sodium and potassium, a spectrophotometer to determine the amount of phosphorus, titration to measure calcium and magnesium, titration with the color variation of the OrthoPhenanthroline ferrous for the measurement of organic carbon and a hydrometer for the detection and measurement of the soil texture. The highest amount of salinity, total nitrogen, and organic carbon were obtained in the soil of the Salt Lake station (central area) and the least amount of these elements were found in the soil of the Darband Shoor Mountain (Table 3).

\section{Statistical analysis}

The data were analyzed using Spearman's rho correlation coefficient test method, also charts were analyzed by IBM SPSS Statistics 23 and Excel 2013 software. Frequency and frequency percentage of samples found in each station (Figure 3), Frequency and frequency percentage of samples found in each month (Figure 4) were investigated. The correlation coefficient of the physical and chemical parameters of the soil in each station and the frequency of species at each station was calculated by Spearman's rho correlation coefficient test and its results are presented in Table 4.

Table 2. Type of vegetation at each station (Species are arranged in family and subfamily order)

\begin{tabular}{ll}
\hline Location & Plant species \\
\hline Salt Lake (Central area) & None \\
Salt Lake (Marginal areas) & Alhagi camelorum, Alhagi maurorum, Prosopis farcta, Scariola orientalis, Launaea \\
& $\begin{array}{l}\text { acanthodes, Arthrocnemum macrostachyum, Bassia indica, Chenopodium album, Halopeplis } \\
\text { perfoliata, Haloxylon salicornicum, Salsola stocksii, Atriplex prostrata, Cressa cretica }\end{array}$ \\
Sadr Abad Historical Caravanserai & Alhagi persarum, Launaea acanthodes, Prosopis farcta \\
Qomrood salt pans & Alhagi camelorum, Alhagi maurorum, Prosopis farcta, Echinops ritro, Launaea acanthodes, \\
& Atriplex prostrata, Atriplex halimus, Cornulaca aucheri, Suaeda vermiculata, Zygophyllum \\
& simplex \\
Darband Shoor Mountain & Scariola orientalis, Launaea acanthodes, Arthrocnemum macrostachyum, Bassia indica, \\
& Chenopodium album, Halopeplis perfoliata, Salsola stocksii, Salsola sp., Atriplex prostrata, \\
& Cressa cretica, Chrozophora tinctoria, Sporobolus spicatus, Zygophyllum simplex
\end{tabular}


Table 3. Physical and chemical parameters of soil in stations

\begin{tabular}{|c|c|c|c|c|c|c|c|c|c|c|c|c|c|c|}
\hline Name & Texture & $\underset{\%}{\text { Clay }}$ & $\begin{array}{c}\text { Silt } \\
\%\end{array}$ & $\begin{array}{l}\text { Sand } \\
\%\end{array}$ & $\begin{array}{c}\mathrm{Ec} \\
\mathrm{ds} / \mathrm{m}\end{array}$ & pH & $\begin{array}{l}\text { Total } \\
\text { N \% }\end{array}$ & $\begin{array}{c}\text { O.C } \\
\%\end{array}$ & $\begin{array}{c}\text { P } \\
\text { (ave) } \\
\text { p.p.m }\end{array}$ & $\begin{array}{c}\text { K } \\
\text { (ave) } \\
\text { p.p.m }\end{array}$ & $\underset{\mathrm{meq} / \mathrm{L}}{\mathrm{mg}}$ & $\begin{array}{l}\mathrm{Ca} \\
\mathrm{meq} / \mathrm{L}\end{array}$ & $\begin{array}{c}\mathrm{Na} \\
\mathrm{meq} / \mathrm{L}\end{array}$ & S.A.R \\
\hline Salt Lake (Central area) & Flocculated & - & - & - & 153.15 & 7.11 & 0.26 & 3.05 & 5.8 & 244.2 & 36 & 72 & 46 & 6.26 \\
\hline Salt Lake (Marginal areas) & Sandy loam & 12 & 26 & 62 & 92.57 & 8.14 & 0.028 & 0.271 & 14.2 & 356 & 20 & 19 & 44 & 9.97 \\
\hline $\begin{array}{l}\text { Historical Caravanserai of } \\
\text { Sadr Abad }\end{array}$ & Sandy loam & 16 & 26 & 58 & 93.58 & 7.86 & 0.069 & 0.687 & 15.4 & 508.4 & 23 & 18 & 43 & 9.51 \\
\hline Salt pans of Qomrood & Silty loam & 22 & 52 & 26 & 84.26 & 7.12 & 0.028 & 0.271 & 11.8 & 305.2 & 9 & 14 & 12 & 3.53 \\
\hline Darband Shoor Mountain & Sandy loam & 10 & 16 & 74 & 72.14 & 12.04 & 0.019 & 0.18 & 7.2 & 274.6 & 6 & 9 & 8 & 2.93 \\
\hline
\end{tabular}

\section{RESULTS AND DISCUSSION}

One hundred twenty-one (121) specimens comprising nine species of five genera and five tribes belonging to the two subfamilies of Myrmicinae and Formicinae were collected and identified.

\section{Subfamily Myrmicinae (Fargeau, 1835) \\ Tribe Stenammini (Ashmead, 1905)}

Of this tribe, only one genus and one species were collected and identified.

Genus Messor (Forel, 1890)

Messor ebeninus (Santschi, 1927) (Figure 3)

Material: 13 , , Beside the salty rock, Darband Shoor Mountain, Iran, 34²5'50.9"N, 50³8'46.9"E, 1258 m, 3 April, 12 May and 8 October 2017, Mohammad Reza Mohseni, Hand Coll., (HMIM).

Description and Diagnosis: Body monochromatic, dark brown to black; worker's Head large and broad, Underside of the head with long J-shaped hairs; antennae 12segmented, the first funiculus segment taller and wider than the second; propodeum angular; postpetiole dome-shaped, postpetiole attached medioventrally to first gastral segment; gaster pyriform from above, dorsal surface of gaster with a few number of hairs or no hair.

Distribution: Collected only from the Darband Shoor Mountain station in April, May, and October.

\section{Tribe Solenopsidini (Forel, 1893)}

Two genera and two species were collected and identified.

\section{Genus Monomorium (Mayr, 1855)}

Monomorium indicum (Forel, 1902) (Figure 4)

Material: 6 , Beside the Salt marsh, Salt Lake (margins), Iran, 34 $57^{\prime} 45.1^{\prime \prime N}, 50^{\circ} 53^{\prime} 37.0 " \mathrm{E}, 809 \mathrm{~m}, 12$ April, 6 July, 9 September and 21 October 2017. Mohammad Reza Mohseni, Hand Coll., (HMIM). 8 , Beside the salty rock, Darband Shoor Mountain, Iran, 34²5'50.9"N, 50³8'46.9"E, 1261 m, 3 April, 23 July, 12 September and 8 October 2017, Mohammad Reza Mohseni, Hand Coll., (HMIM).

Description and Diagnosis: Head and thorax dark brown; surface of the head with net-like patterns; compound eyes relatively large; antennae 12-segmented, terminal funiculus segment as long as two preceding segments; clypeus with anterior long setae; metanotal suture well developed; propodeum curved and without spine; petiole distinctly pedunculated to subsessile, petiole slightly longer than the postpetiole, postpetiole attached medioventrally to first gastral segment; the gaster pyriform from above, dorsal surface of the abdomen with no hair.

Distribution: Collected from the Salt Lake (margins) and the Darband Shoor Mountain in April, July, September, and October.

\section{Monomorium rimae n. sp. (Collingwood \& Agosti 1996) (Figure 5)}

Material: 2 , Beside the Salt marsh, Salt Lake (margins), Iran, 3457'45.1"N, 5053'37.0"E, 808 m, 12 April 2017, Mohammad Reza Mohseni, Hand Coll., (HMIM).

Description and Diagnosis: Bicoloured, alitrunk brown contrasting with glossy black gaster; head, gaster and legs shiny dark brown and darker than alitrunk; head and alitrunk with net-like patterns; antennae 12-segmented, terminal funiculus segment approximately longer than the two preceding segments together; propodeum curved and without the spine; petiole slightly longer than the postpetiole; the gaster pyriform from above.

Distribution: Collected only from the Salt Lake station (margins) in April.

\section{Tribe Crematogastrini (Forel, 1893)}

Of this tribe, one genus and one species were collected and identified.

Genus Tetramorium (Mayr, 1855)

Tetramorium sp. (Mayr, 1855) (Figure 6)

Material: $10 \%$, Beside the salty rock, Darband Shoor Mountain, Iran, 34² $5^{\prime} 50.9^{\prime \prime} \mathrm{N}, 50^{\circ} 38^{\prime} 46.9^{\prime \prime E}, 1259 \mathrm{~m}, 3$ April and 12 May 2017, Mohammad Reza Mohseni, Hand Coll., (HMIM).

Description and Diagnosis: Head and neck brownishblack, antennae, legs and thorax dark red; antennae 12segmented; head and alitrunk strongly sculptured; clypeus raised into a ridge in front of the antennal insertions; alitrunk with hairs scattered over whole dorsum; mid and hind tibial spurs simple; propodeal spines strongly 
developed; petiole with distinct dorsal sculpture; petiole and postpetiole square-shaped; postpetiole attached medioventrally to first gastral segment, the gaster pyriform from above.

Distribution: Collected only from the Darband Shoor Mountain Station in April and May.

\section{Subfamily Formicinae (Lepeletier, 1836) \\ Tribe Formicini (Latreille, 1809)}

One genus and four species were identified.

Genus Cataglyphis (Förster, 1850)

Cataglyphis niger (André, 1881) (Figure 7)

Material: 5 , Beside the salty rock, Darband Shoor Mountain, Iran, $34^{\circ} 25^{\prime} 50.9^{\prime \prime} \mathrm{N}, 50^{\circ} 38^{\prime} 46.9^{\prime \prime} \mathrm{E}, 1259 \mathrm{~m}, 23$ July and 8 October 2017, Mohammad Reza Mohseni, Hand Coll., (HMIM).

Description and Diagnosis: Size ranges from 5 to 13 $\mathrm{mm}$; body-color entirely black or brownish-black; ocelli present; antennae 12-segmented, the first funiculus longer than the second, antennal insertions close to the clypeal margin; mandibles triangular; the exterior surface of tibiae without setae; orifice of propodeal spiracle elongate slit or oval-shaped; petiole dome-shaped.

Distribution: Collected only from the Darband Shoor Mountain Station in July and October.

\section{Cataglyphis bellicosus (Karavaiv, 1924) (Figure 8)}

Material: 6 , Beside the Salt marsh, Salt Lake (margins), Iran, 3457'45.1"N, 5053'37.0"E, 809 m, 12 April, 12 May, 21 October, and 17 November 2017. Mohammad Reza Mohseni, Hand Coll., 10 ㅇ, Beside the salty rock, Darband Shoor Mountain, Iran, 34 ${ }^{\circ} 25^{\prime} 50.9^{\prime \prime} \mathrm{N}$, 50³8'46.9"E, $1261 \mathrm{~m}, 3$ April, 23 July, 12 September 8 October 2017, Mohammad Reza Mohseni, Hand Coll., 4 q On Salt Fields (Beside the Shrubs), Salt pans of Qomrood, Iran, 3443'33.3"N, 51 ${ }^{\circ} 03^{\prime} 57.7^{\prime \prime E}, 844$ m, 3 April, 12 May, 8 October and 17 November 2017, Mohammad Reza Mohseni, Hand Coll., (HMIM).

Description and Diagnosis: Size ranges from 5 to 13 $\mathrm{mm}$; uniformly dark brown to black, head sometimes slightly red tint; ocelli present; antennae 12-segmented, antennal insertions close to the clypeal margin; mandibles triangular; the exterior surface of tibiae bears coarse; the fourth and fifth spiracles of the gaster visible and, in some cases, the fourth to seventh spiracles covered by the margin of the preceding segment; petiole dome-shaped.

Distribution: Collected from the Salt Lake stations (margins), Darband Shoor Mountain and salt pans of Qomrood in April, May, October, and November.

\section{Cataglyphis setipes (Forel, 1894) (Figure 9)}

Material: 12 , On Salt Fields (Beside the Shrubs), Salt pans of Qomrood, Iran, 34 $43^{\prime} 33.3^{\prime \prime} \mathrm{N}, 51^{\circ} 03^{\prime} 57.7^{\prime \prime E}, 843$ m, 12 May, 8 October and 17 November 2017, Mohammad Reza Mohseni, Pitfall, (HMIM).
Description and Diagnosis: Size ranges from 5 to 13 $\mathrm{mm}$; head and thorax of different tints of red; abdomen blackish brown to black; ocelli present; antennae 12segmented, antennal insertions close to the clypeal margin; mandibles triangular; the exterior surface of tibiae bears coarse, tibial spurs present; petiole dome-shaped.

Distribution: Collected only from the salt pans of Qomrood in May, October, and November.

Cataglyphis lividus (André, 1881) (Figure 10)

Material: 12 , Salt marsh (Exactly on the salt), Salt Lake (Central area), Iran, 3458'03.4"N, 5054'05.8"E, 804 m, 12 April, 12 May, and 21 October 2017. Mohammad Reza Mohseni, Pitfall, 10 \%, Beside the Salt marsh, Salt Lake (margins), Iran, 3457'45.1"N, 5053'37.0"E, 809 m, 12 April, 12 May and 21 October 2017, Mohammad Reza Mohseni, Hand Coll., 1 q, On salty soils, Historic Caravanserai of Sadr Abad, Iran, 34 53'05.3"N, 51 04'41.1"E, 806 m, 12 April, 12 May and 21 October 2017, Mohammad Reza Mohseni, Hand Coll., 5 ㅇ, On Salt Fields (Beside the Shrubs), Salt pans of Qomrood, Iran, 34 43 '33.3"N, 51 ${ }^{\circ} 03^{\prime} 57.7^{\prime} \mathrm{E}, 843 \mathrm{~m}, 3$ April, 12 May and 8 October 2017, Mohammad Reza Mohseni, Pitfall, (HMIM).

Description and Diagnosis: Size ranges from 3.5 to 3.8 $\mathrm{mm}$; body uniformly yellowish-orange; gaster glossy; ocelli present; antennae 12-segmented, antennal insertions close to the clypeal margin; occiput and notum without upright hairs; the exterior surface of tibiae bears coarse; frontal margin of clypeus with long setae; petiole coneshaped.

Distribution: Collected from all the stations except for Darband Shoor Mountain in April, May, and October.

\section{Tribe Plagiolepidini (Forel, 1886)}

This tribe, only one species were collected and identified.

Genus Lepisiota (Santschi, 1926)

Lepisiota dolabellae (Forel, 1911) (Figure 11)

Material: 17 q, On Salt Fields (Beside the Shrubs), Salt pans of Qomrood, Iran, 3443'33.3"N, 51 ${ }^{\circ} 03^{\prime} 57.7^{\prime \prime E}, 844$ m, 12 May and 17 November 2017, Mohammad Reza Mohseni, Pitfall, (HMIM).

Description and Diagnosis: Bicoloured ants; head and gaster dark brown; alitrunk legs and antennae brighter; all parts of the body shining with superficial reticulate sculpture; antennae 12-segmented; antennal scape long, over-reaching the occipital margin by half of its length; antennal insertions contiguous with the clypeal margin; Propodeum bituberculate or bidentate; the pronotum with one or two pairs of fine hairs; dorsal edge of petiole armed with a pair of teeth.

Distribution: Collected only from the Qomrood's salt pans station in May and November. 


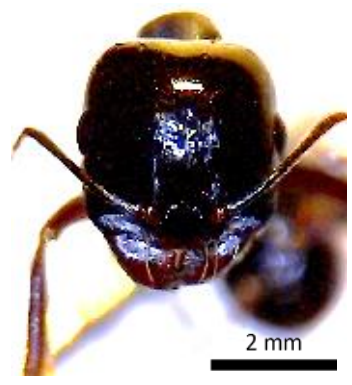

A

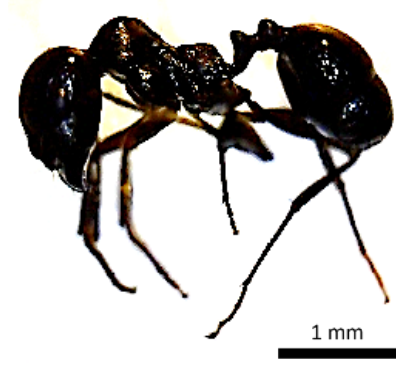

B

Figure 3. Messor Ebeninus (Santschi, 1927). A. Head, front view, B. Body, side view

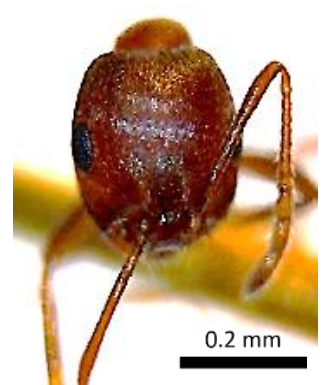

A

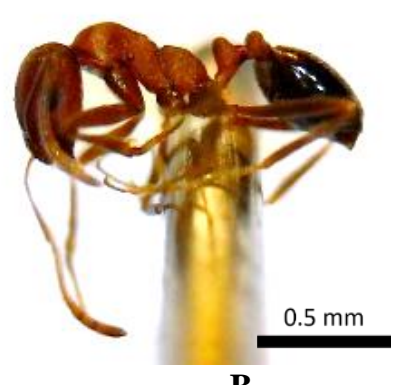

B

Figure 4. Monomorium indicum (Forel, 1902). A. Head, front view, B. Body, side view

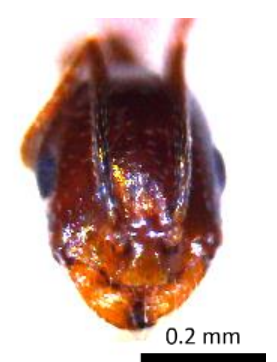

A

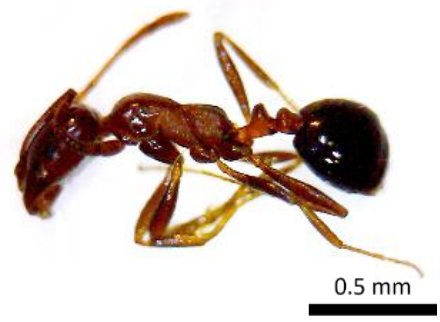

$\mathbf{B}$

Figure 5. Monomorium rimae n. sp. (Collingwood \& Agosti 1996). A. Head, front view, B. Body, side view

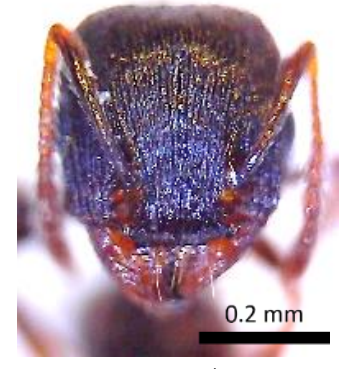

A

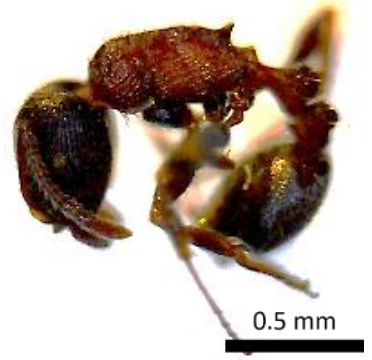

B

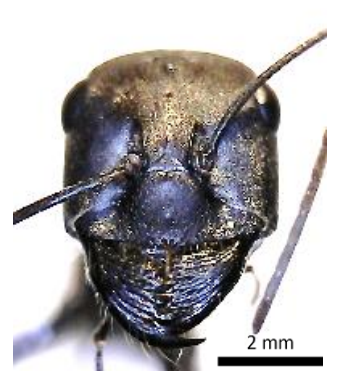

A

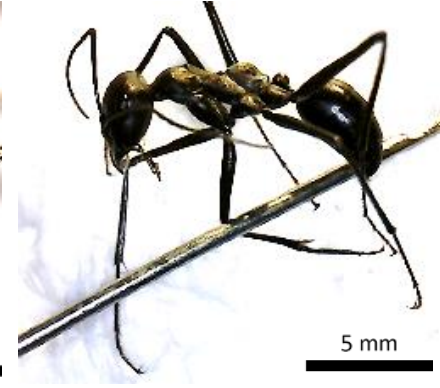

B

Figure 7. Cataglyphis niger (André, 1881). A. Head, front view, B. Body, side view

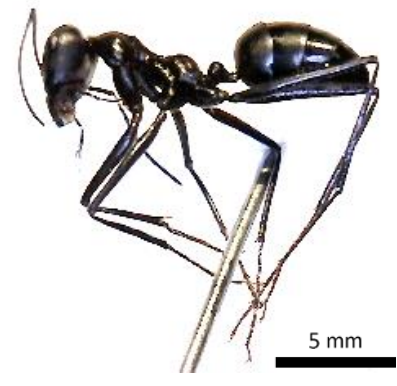

B

Figure 8. Cataglyphis bellicosus (Karavaiev, 1924). A. Head, front view, B. Body, side view

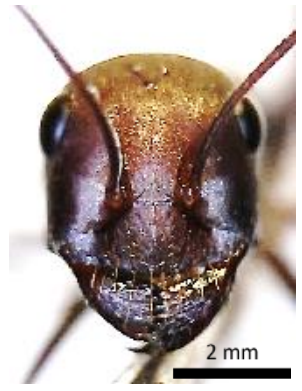

A

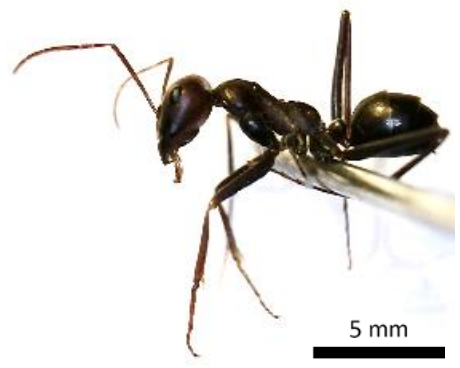

B

Figure 9. Cataglyphis setipes (Forel, 1894). A. Head, front view, B. Body, side view

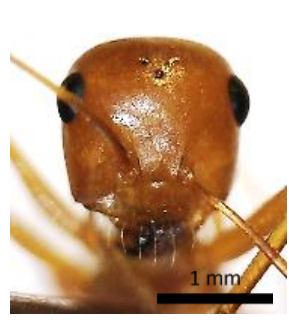

A

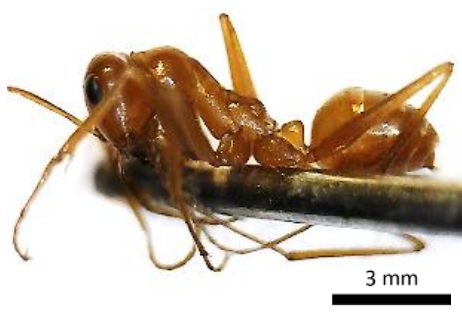

B

Figure 6. Tetramorium sp. (Mayr, 1855). A. Head, front view, B. Body, side view;

Figure 10. Cataglyphis lividus (André, 1881). A. Head, front view, B. Body, side view; 


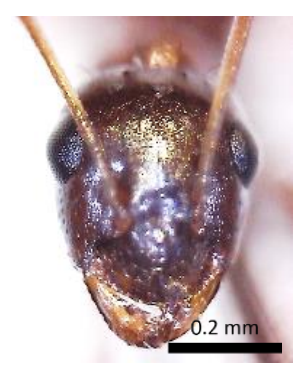

A

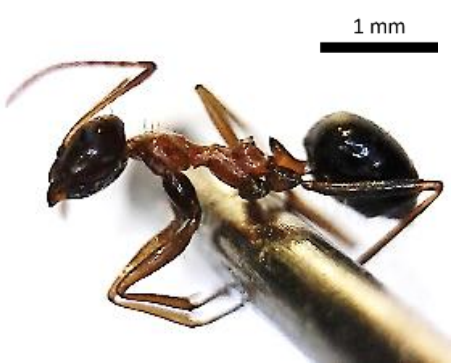

B
Figure 11. Lepisiota dolabellae (Forel, 1911). A. Head, front view, B. Body, side view

\section{The frequency of species found in each station}

The abundance and the percentage frequency distribution of ant species found from each station are shown in Figure 12. As can be seen, from the Salt Lake (Central area) Station, only 12 Specimens of Cataglyphis lividus were observed. At the salt lake (marginal areas) station, Monomorium rimae n. sp., Monomorium indicum, Cataglyphis bellicosus, and C. lividus were found with two, six, six, and ten samples respectively. Only one species of C. lividus was observed from Sadr Abad Historical Caravanserai. From the Qomrood salt pans, four specimens of C. bellicosus, 12 specimens of Cataglyphis setipes, five specimens of C. lividus and 17 specimens of Lepisiota dolabellae were observed. At the Darband Shoor Mountain station, 13 samples belonged to the Messor ebeninus species, and eight samples belonged to $M$. indicum, ten samples of Tetramorium sp., five Specimens of the Cataglyphis niger And ten samples belonged to Ctaglyphis bellicosus were observed (Figure 12.A.). As can be seen, the highest frequency belonged to $C$. lividus (23\%). The $C$. bellicosus (16\%), L. dolabellae (14\%) and M. indicum (12\%) were ranked next, respectively. The lowest frequency belonged to M. rimae n. sp. was $2 \%$ (Figure 12.B.).

\section{Analysis of found samples frequency per month}

The abundance and the percentage frequency distribution of ant species found in different months are given in Figure 13. Results show that in April, the M. rimae n. sp., with two specimens, M. ebeninus, $M$. indicum and $C$. setipes with five specimens, separately and $C$. bellicosus with six and $C$. lividus with seven samples were found. In May, the M. ebeninus, Tetramorium sp., Cataglyphis stipes, C. bellicosus, L. dolabellae, and C. lividus with three, four, four, five, five, and nine samples were observed, respectively. In July, two individuals belong to $M$. indicum, two individuals belong to C. bellicosus, and three individuals belong to $C$. niger were recorded. Results for September represents two founded samples for C. niger, four samples belonged to Monorium indicum and $C$. bellicosus, separately and five, six, eight and eight belonged to M. ebeninus, Tetramorium sp., C. lividus and L. dolabellae, respectively. Results for October indicates 3 specimens for each species of M. indicum, C. bellicosus, and $C$. setipes, also Four species were recorded for each species of C. lividus and L. dolabellae (Figure 13.A.). As can be seen, September had the highest percentage of ants species with $31 \%$, and the lowest percentage of ants species belonged to July with 5\%, Also, May with 25\%, April with $23 \%$ and October with $16 \%$ are reported (Figure 13.B.).

The comparison of the results of sampling in three seasons shows that the first half of the spring season with favorable climate conditions and the highest number of herbaceous species such as Atriplex prostrata, Chenopodium album and Sporobolus spicatus had the most frequent samples recorded at Darband Shoor Mountain, while in the second half of the spring and the summer season, due to the increase in temperature, decreasing moisture content and the growth rate of some plant species, only a few numbers of samples were collected from the stations (Figure 4).

\section{Correlation coefficient test}

Based on the results of Spearman's rho correlation coefficient test which was performed between salinity, $\mathrm{pH}$, organic carbon percentage and total nitrogen percentage of each station with the frequency of species at sampling stations, there was a negative significant correlation between soil salinity and the frequency of species (Table 4). Thus, increasing the soil salinity at different stations reduces the frequency of observed species, whereas there was no significant correlation between $\mathrm{pH}$, organic carbon percentage and total nitrogen content in sampling station soils with the frequency of species (Table 4).

\section{Discussion}

Taking into consideration of all the stations, it was found that Darband Shoor Mountain had the highest number of species with five species, followed by Salt Lake (margins) and the salt pans of Qomrood each with four species whereas Salt Lake stations (central area) and Sadr Abad Historical Caravanserai each with one species. The species of $C$. lividus collected from Salt Lake stations (central area), Salt Lake (margins), and Sadr Abad Historical Caravanserai and Qomrood Salt pans were identified as the dominant species in the region.

Table 4. Investigating the relationship between number of species and measured parameters

\begin{tabular}{lcccc}
\hline Parameter & $\begin{array}{c}\text { Soil salinity } \\
(\mathbf{d s} / \mathbf{m})\end{array}$ & $\mathbf{p H}$ & $\begin{array}{c}\text { Total N } \\
(\%)\end{array}$ & $\begin{array}{c}\text { Organic } \\
\text { carbon }(\%)\end{array}$ \\
\hline Frequency of & $-0.9^{*}$ & $0.5 \mathrm{~ns}$ & $-0.872 \mathrm{~ns}$ & $-0.872 \mathrm{~ns}$
\end{tabular}

spices

Note: $n s, \mathrm{P}>0.05, * \mathrm{P}<0.05$ 


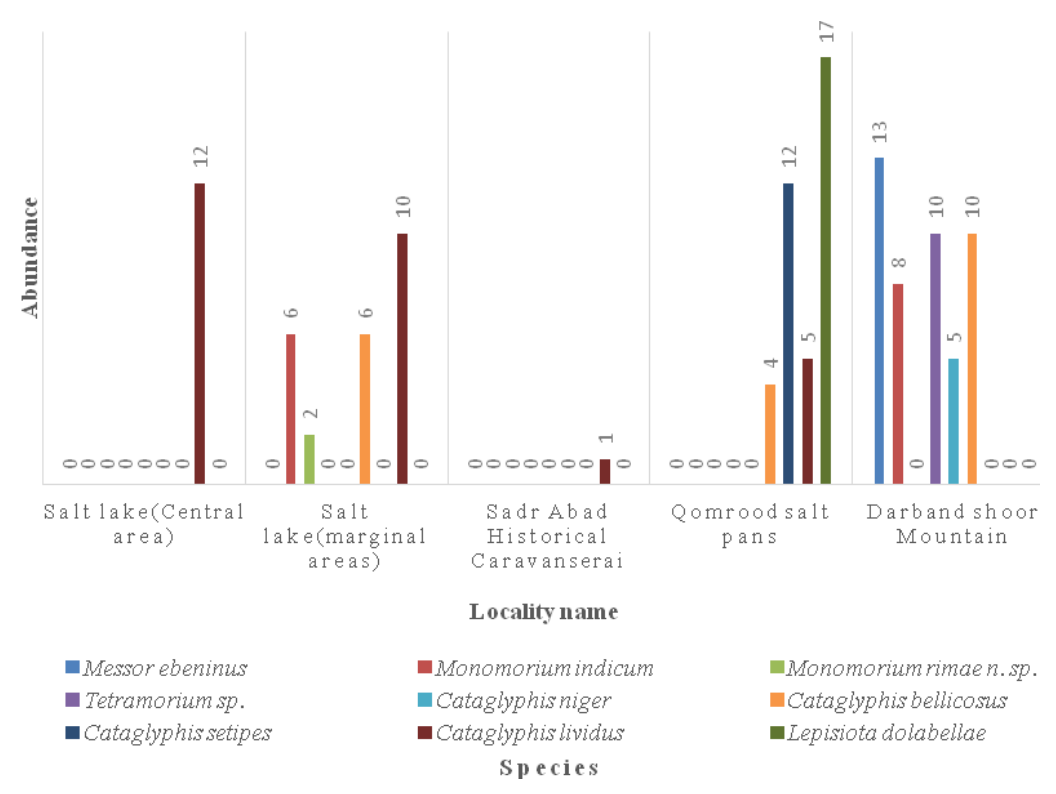

A

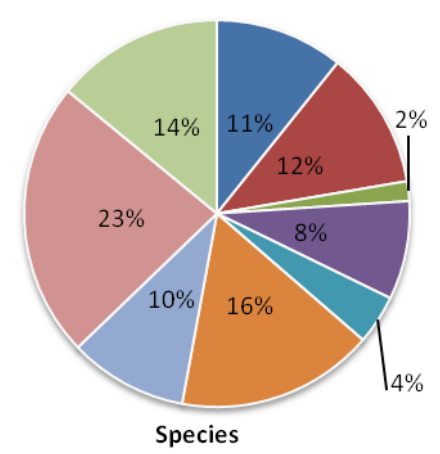

-Messor ebeninus

-Monomoriumindicum

Monomorium rimaen.sp.

- Tetramoriumsp.

-Cataglyphisniger

- Cataglyphis bellicosus

Cataglyphissetipes

-Cataglyphislividus

Lepisiota dolabellae

Figure 12. Samples found from each species at each station. A. Abundance, B. Percentage frequency distribution

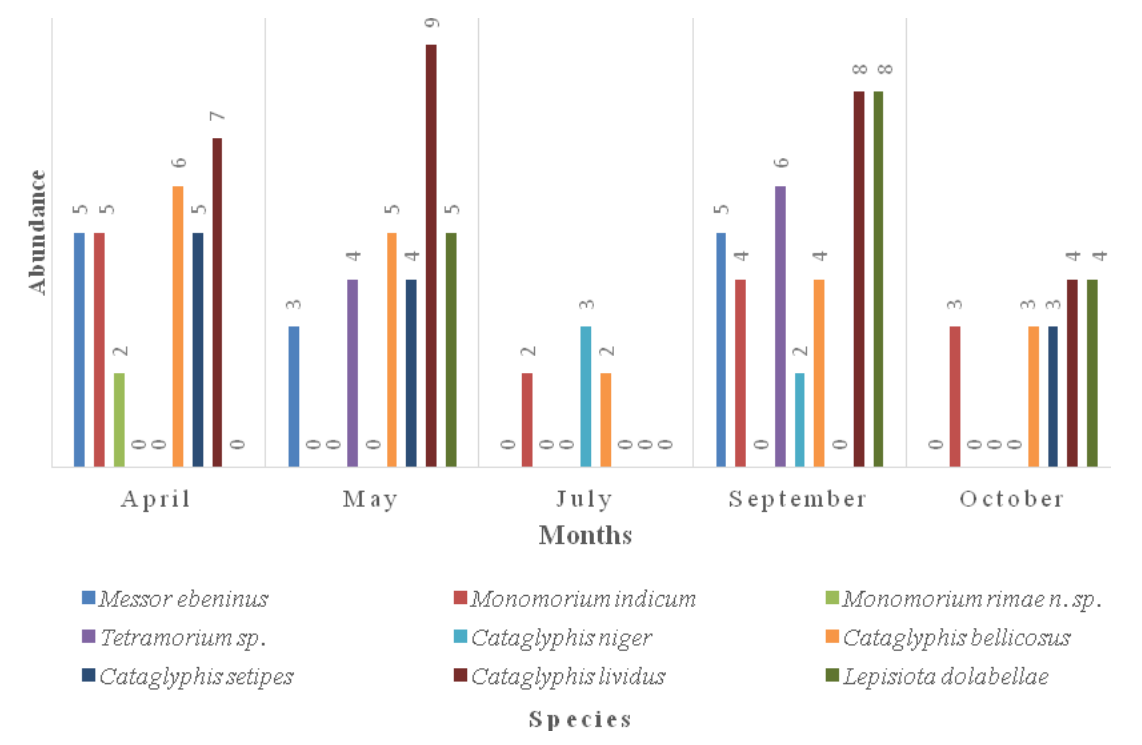

A

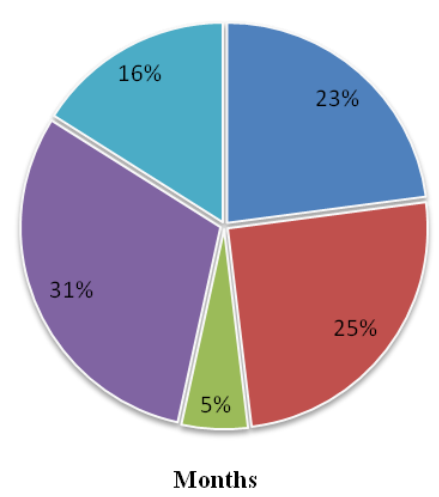

$\square$ April

घay

$\square$ July

- September

October

B

Figure 13. Samples found from each species per month. A. Abundance, B. Percentage frequency distribution

According to the prevalence of Cataglyphis, especially C. lividus species as the most dominant species in all stations and based on the individual physical features of this species, it seems that the presence of long legs in Cataglyphis species makes them more compatible for living in salt marshes and salt deserts while species with short legs in these areas were not found. Sommer and Wehner (2012) reports on the inadaptability and lack of distribution of short-legged species of ants in scorching and salt deserts regions, as well as the study conducted by Mohseni (2018) which did not find species with short legs from the salt marshes and salt deserts of central parts of Iran all, confirm this fact.

Studies conducted by Heatwole (2001), Wolf et al. (2018) and Mohseni (2018) reported the presence of Cataglyphis in Kalahari Desert in southern Africa, the Maharès Desert in Tunisia and the central salt deserts of Iran with a warm and dry climate which all strengthen the results of this research, and justified the dominance of species with longer legs and larger bodies such as Cataglyphis (e.g. C. lividus and C. bellicosus) and Lepisiota (e.g. L. dolabellae). 
In studies by Stieb et al. (2011), Cataglyphis species such as C. rubra and C.albicans were were collected and identified from Menzel Chaker town in Tunisia, while Dahmen et al. (2017) found $C$. fortis and $C$. bicolor in salt deserts around Maharès in Tunisia. In the present study, $C$. lividus, $C$. bellicosus, $C$. setipes, and $C$. niger species were collected from salt marshes, salt pans and hot areas in central parts of Iran, which confirmed the abovementioned studies and indicated the adaptability of these species with salt deserts and poor vegetation cover. On the other hand, in wet climates and dense vegetation, such as in the Assam State of India (Bharti et al. 2016) and Guilan Province of Iran (Ghatei 2016) no Cataglyphis species can be found, indicating that this genus is found in hot, dry and salt pans areas.

Because of factors including special geographic location, topology, various climatic conditions and vegetation such as Alhagi maurorum, Prosopis farcta, Scariola orientalis, Launaea acanthodes, Bassia indica, Halopeplis perfoliata, Atriplex prostrata, Cressa cretica and Zygophyllum simplex (Table 2), Darband Shoor Mountain station is considered to be a more suitable habitat for diversity of ants than other stations. The stations of the Historic Caravanserai of Sadr Abad and the Salt Lake (central area) with very poor ecological conditions, dry and desert climate and very poor vegetation (only Alhagi persarum, Launaea acanthodes, and Prosopis farcta) (Table 2) had a poorer species diversity than other stations in salt-marshlands and pans. An interesting point in this regard was the presence of $C$. lividus colonies near the Alhagi species. It seems that there is a kind of symbiosis between these two species. As we found the food's source of $C$. lividus right next to the root of Alhagi species. In this regard, it is hypothesized that $C$. lividus protects the plant against harmful insects. No similar study found, however.

Few studies have been conducted in salt pans and salt marshes. Palomo et al. (2003) have collected only one species (Solenopsis richteri) from the salt marshes of the Mar Chiquita area in southeastern Buenos Aires in Argentina with a very mild temperate climate and an altitude of about 70 meters above the sea level. This station had the rich and dense plants species such as Spartina densiflora, Stenotaphrus secundatum, Salicornia virginica, Limonium brasiliense, and Juncus acutus. Moore et al. (2013) conducted their research in the salt marshes of Ballona Wetlands in southern California which has relatively warm Mediterranean climate and an altitude of about 34 meters above the sea level with relatively suitable vegetation cover such as Chaenactis glabriuscula (Agostoni 2010) and found Linepithema humile. Loken and Oliver (2016) reported a species called Crematogaster pilosa from salt pans and salt marshes of Sapelo Island, Georgia, in the south-east of the United States of America with a warm climate, relatively high humidity and an altitude of 5 meters above sea level and suitable vegetation such as Spartina alterniflora, Batis maritima, Juncus roemerianus, Borrichia frutescens (Reidenbaugh and Banta 1980; Howes et al. 1981; Schalles et al. 2013). In studies carried out by Dahmen et al. (2017) Cataglyphis fortis and Cataglyphis bicolor were collected and identified from the rainforests around Maharès in the eastern part of Tunisia with relatively high humidity and an altitude of $22 \mathrm{~m}$ and a relatively poor vegetation such as Salsola kali, Limoniastrum monopetalum, Olea europaea and Rosmarinus officinalis (You et al. 2016).

Among the other studies carried out in different areas with different ecological conditions are Orabi et al. (2011) that reported $C$. niger and Cataglyphis ruber species at habitats with altitudes of 1640 and $1730 \mathrm{~m}$ in the mountainous city of St. Catherine located in South Sinai Governorate in Egypt. Bharti et al. (2014) found Cataglyphis cugiai at altitudes of 2000 and $2750 \mathrm{~m}$ in Bhaderwah and Kargil, India respectively. Nafisi (2014) and Aram (2015) found C. bellicosus and Cataglyphis nodus in Sabzevar City and Ardabil Province, Iran. Together with our study which was conducted at altitudes of 804 to 1259 meters with warm and dry climates and poor vegetation, the presence of Cataglyphis, it seems that Cataglyphis species has adaptability with varying altitudes and environmental conditions.

The presence of $L$. dolabellae from the salt pans of the central regions of Iran (Qomrood salt pans station) with a very hot and dry climate, confirmed the findings by Collingwood and Agosti (1996) in the desert areas of Saudi Arabia with very hot climate and very poor vegetation. The presence of this species and some other species from this genus in other parts of the world with very humid, mild, tropical and Mediterranean, dry and very hot climate with different types of vegetation indicate the high adaptability of this genus to various climatic conditions and vegetation cover (Orabi et al. 2011; Mifsud et al. 2011; Borowiec and Salata 2012; Guénard and Dunn 2012; Ghatei 2016).

To conclude, in the present study that carried out in salt marshes and salt pans of the central parts of Iran, nine species belonging to four genera and 2 subfamilies were collected and identified. C. lividus was the dominant species in all stations except in Darband Shoor Mountain, whereas Monomorium rimae $\mathrm{n}$. sp. was collected only from Salt Lake (Marginal areas). Darband Shoor Mountain which had the highest vegetation density and the lowest salinity of soil $(72.14 \mathrm{dS} / \mathrm{m})$ had the highest ant diversity with five species whereas Salt Lake (Central area) with no vegetation and the highest salinity of soil $(153.15 \mathrm{dS} / \mathrm{m})$ had only one species. C. lividus as the dominant species showed a high adaptation across all habitats. We found that although some ant species have a lesser presence in these areas, generally the ant species have entirely adapted to the specific environmental conditions in the salt marshes and salt pans. One of the most interesting findings of this study was the presence of $C$. lividus species in salt marshes without any vegetation cover in the central area of the Salt Lake, indicating a high adaptation of this species to salt pans and salt marshes.

\section{ACKNOWLEDGEMENTS}

We thank Prof. Brian Taylor from the Royal Entomological Society of London, England for his guidance and approving the identified species. We are 
grateful to the Iran Meteorological Organization Management Committee for permission to access the data. We are also grateful to Dr. Mehrabian to identify plant species.

\section{REFERENCES}

Agosti D, Johnson NF. 2003. In: Fernández F (ed). La nueva taxonomía de hormigas. Introducción a las hormigas de la región neotropical. Instituto Humboldt, Bogotá.

Agostoni K. 2010. Rare plant species discovered at Sand Dune Park. The Daily Breeze. Retrieved 3 March 2018.

Aram E. 2015. Faunistic investigation and biodiversity of ants (Hymenoptera: Formicidae) in the Khvoresh Rostam District, Khalkhal County, Ardabil Province, Iran. [Thesis]. Islamic Azad University, Tehran Medical Branch, Iran.

Ardeh MJ. 1994. Investigating characteristics and behavioral characteristics of the ants in Karaj city. [Thesis]. Tehran University, Tehran, Iran.

Belchior C, Sendoya SF, Del-Claro K. 2016. Temporal variation in the abundance and richness of foliage-dwelling ants mediated by extrafloral nectar. PLoS ONE 11 (7): e0158283. DOI: 10.1371/ journal. pone. 0158283

Bharti H, Gu I, Dubovikoff DA. 2014. First description of male of Cataglyphis cugiai Menozzi, 1939 (Hymenoptera: Formicidae) from Himalaya, with notes on the species ecology and biodiversity conservation of the region. Entomol Bull 10 (1): 137-139. DOI: 10.23885/1814-3326-2014-10-1-137-139.

Bharti H, Guénard B, Bharti M, Economo EP. 2016. An updated checklist of the ants of India with their specific distributions in Indian states (Hymenoptera, Formicidae). Zookeys 551: 1-83.

Bolton B. 1994. Identification Guide to the Ant Genera of the World. Harvard University Press. Cambridge, MA, USA.

Borowiec L, Salata S. 2012. Ants of Greece-checklist, comments and new faunistic data (Hymenoptera: Formicidae). Genus 23 (4): 461-563.

Cardoso DC, Schoereder JH. 2014. Biotic and abiotic factors shaping an (Hymenoptera: Formicidae) assemblages in Brazilian Coastal Sand Dunes: The case of Restinga in Santa Catarina. Fla Entomol 97 (4): 1443-1450. DOI: 10.1653/024.097.0419

Clark AT, Rykken JJ, Farrell BD. 2011. The effects of biogeography on ant diversity and activity on the Boston Harbor Islands, Massachusetts, U.S.A. PLoS One 2011; 6 (11): e28045. DOI: 10.1371/journal.pone.0028045

Collingwood CA. 1985. Hymenoptera: Fam. Formicidae of Saudi Arabia. Fauna of Saudi Arabia 7: 230-302.

Collingwood CA, Agosti D. 1996. Formicidae (Insecta: Hymenoptera) of Saudi Arabia (Part 2). Fauna of Saudi 15: 300-385.

Dahmen H, Wahl VL, Pfeffer SE, Mallot HA, Wittlinger M. 2017. Naturalistic path integration of Cataglyphis desert ants on an aircushioned lightweight spherical treadmill. J Exp Biol 2017 220, 634644. DOI: $10.1242 /$ jeb. 148213 .

Davis LV, Gray IE. 1966. Zonal and seasonal distribution of insects in North Carolina salt marshes. Ecol Monogr 36: 275-295. DOI: $10.2307 / 1942419$.

Emery C. 1906. Rassegna critica delle specie paleartiche del genere Myrmecocystus. Memorie Reale Accademia Scienze dell'istituto di Bologna 6 (3): 173-187.

Folgarait PJ. 1998. Ant biodiversity and its relationship to ecosystem functioning: a review. Biodivers Conserv 7: 1221.7 (9): 1221-1244. DOI: 10.1023/a: 1008891901953.

Foster WA, Treherne JE. 1976. Insects of marine saltmarshes: Problems and adaptations. pp. 5-42 In Cheng L [ed.], Marine Insects. NorthHolland Publishing Company, Amsterdam, Holland.

Forel A, 1904. Dimorphisme du mâle chez les fourmis et quelques autres notices myrmécologiques. Annales de la Société Entomologique de Belgique 48: 421-425.

Ghatei KM. 2016. Faunistic investigation and biodiversity of ants (Hymenoptera: Formicidae) in the Northern part of Guilan Province, Iran. [Thesis]. Shahid Beheshti University, Tehran, Iran.

Griffiths HM, Ashton LA, Walker AE, Hasan F, Evans TA, Eggleton P, Parr CL. 2017. Ants are the major agents of resource removal from tropical rainforests. J Anim Ecol 87 (1): 293-300. DOI: $10.1111 / 1365-2656.12728$

Goulet H, Hubert JF. 1993. Hymenoptera of the world. An identification guide to families. Research Branch, Agricultural Canada Publication.Canada Communication Group-Publishing, Ottawa.

Guénard B, Dunn RR. 2012. A checklist of the ants of China. Zootaxa 3558. Magnolia Press, New York.

Hashimoto Y. 2003. Identification Guide to Ant Genera of Borneo. Inventory and Collection. Total protocol for understanding of biodiversity, Chapter 9. Institute for Tropical Biology and Conservation, Universiti Malaysia Sabah and Japan International Cooperation Agency (JICA), Tokyo.

Heatwole H. 2001. Realized ant assemblages in the Namib, Kalahari and Kara-Kum Deserts. In: Prakash I (ed.). Ecology of Desert Environments. Scientific Publishers, Jodhpur, India.

Houadria M, Blüthgen N, Salas-López A, Schmitt MI, Arndt J, Schneider E, Orivel J, Menzel F. 2016. The relation between circadian asynchrony, functional redundancy, and trophic performance in tropical ant communities. Ecology 97 (1): 225-235. DOI: 10.1890/142466.1

Howes BL, Howarth RW, Teal JM, Valiela I. 1981. Oxidation-reduction potentials in a salt marsh: Spatial patterns and interactions with primary production. Limnol. Oceanogr 26 (2): 350-360. DOI: 10.4319/lo.1981.26.2.0350

The Iran Meteorological Organization, 1955. Climatic analysis of central areas of Iran. Received in 1396. Available from http://www.irimo.ir

Jilkova V, Chlumsky J, Koutecky P, Stech M. 2012. Roles of speciespreferential seed dispersal by ants and endozoochory in Melampyrum (Orobanchaceae). J Plant Ecol 6 (3): 232-239. DOI: 10.1093/jpe/rts039

Jones AS. 2008. Fantastic ants-Did you know?. National Geographic Magazine. Archived from the original on 30 July 2008. Retrieved 5 July 2008.

Loken LC, Oliver SK. 2016. Habitat requirements and occurrence of crematogaster pilosa (Hymenoptera: Formicidae) ants within intertidal salt marshes. Fla Entomol 99 (1): 82-88. DOI: 10.1653/ 024. 099.0115.

Luke SH, Fayle TM, Eggleton P, Turner EC, Davies RG. 2014. Functional structure of ant and termite assemblages in old-growth forest, logged forest and oil palm plantation in Malaysian Borneo. Biodivers Conserv 23: 2817-2832. DOI: 10.1007/s10531-014-0750-2.

McCoy ED, Rey JR. 1987. Terrestrial arthropods of northwest Florida salt marshes: Hymenoptera (Insecta). Fla Entomol 70: 90-97. DOI: $10.2307 / 3494762$.

Menozzi C. 1927. Zur Erforschung des Persischen Golfes (Beitrag nr. 12) Formicidae (Hym.). Supp Entomol 16: 117-119.

Mifsud D, Mangion M, Azzopardi E, Espadaler X, Cuesta-Segura D, Watson GW, Perez HN. 2011. Aphids associated with shrubs, herbaceous plants and crops in the Maltese Archipelago (Hemiptera, Aphidoidea). Bul ESM 4: 5-53.

Mohseni MR. 2018. Identification and biodiversity of ants (Formicidae: Hymenoptera) in Qom Province, Iran. [Thesis]. Islamic Azad University, Science and Research Branch, Tehran, Iran. Pp 161.

Moore M, Tansuwan M, Carmona-Galindo VD. 2013. Differential bait preference and rate of attraction by Argentine ants (Linepithema humile Mayr) at freshwater and saltwater marsh sites in southern California. Bios 84 (4): 232-236. DOI: 10.1893/0005-3155-84.4.232

Nafisi FR. 2014. Faunistic investigation and biodiversity of ants (Hymenoptera: Formicidae) in the Sabzevar city and Suburbs, Iran. [Thesis]. Shahid Beheshti University, Tehran, Iran.

Orabi GM, Semida FM, Abdel-Dayem MS, Sharaf MR, Zalat SM. 2011. Diversity patterns of ants along an elevation gradient at St. Catherine Protectorate, South Sinai, Egypt, (Hymenoptera: Formicidae). Zool Middle East 54 (1): 101-112. DOI: 10.1080/0939 7140.2011.10648882

Paknia O, Radchenko A, Pfeiffer M. 2010. New records of ants (Hymenoptera: Formicidae) from Iran. Asian Myrmecol 3: 29-38. DOI: 10.20362/am.003005.

Palomo G, Martinetto P, Perez C, Iribarne O. 2003. Ant predation on intertidal polychaetes in a SW Atlantic estuary. Mar Ecol Prog Ser 253: 165-173. DOI: 10.3354/meps 253165

Pétillon J, Montaigne W, Renault D. 2009. Hypoxic coma as a strategy to survive inundation in a salt-marsh inhabiting spider. Biol Lett 5 (4): 442-445. DOI: 10.1098/rsbl.2009.0127

Pashaei Rad S, Taylor B, Torabi R, Aram E, Abolfathi G, Afshar R, Borjali F, Ghatei M, Hediary F, Jazini F, Heidary KV, Mahmoudi Z, 
Safariyan F, Seiri M. 2018. Further records of ants (Hymenoptera: Formicidae) from Iran. Zool Middle East 64 (2): 145-159. DOI: 10.1080/09397140.2018.1442301

Radchenko AG. 1998. A key to ants of the genus Cataglyphis forester (Hymenoptera, Formicidae from Asia). Entomol Rev 78 (4): 475-480.

Rabeling C, Brown JM, Verhaagh M. 2008. Newly discovered sister lineage sheds light on early ant evolution. PNAS 105 (39): 1491314917. DOI: 10.1073/pnas.0806187105

Reidenbaugh TG, Banta WC. 1980. Origins and effects of Spartina Wrack in a Virginia Salt Marsh. Gulf Res Rep 6 (4): 393-401. DOI 10.18785/grr.060 4. 07

Sanders D, van Veen FJF. 2011, Ecosystem engineering and predation: the multi-trophic impact of two ant species. J Anim Ecol 80: 569-576. DOI: $10.1111 / \mathrm{j} .1365-2656.2010 .01796 . x$

Schalles JF, Hladik CM, Lynes AA, Pennings SC. 2013. Landscape estimates of habitat types, plant biomass, and invertebrate densities in a Georgia salt marsh. Oceanography 26 (3): 88-97. DOI: 10.5670/oceanog. 2013.50

Schultz TR. 2000. In search of ant ancestors. Proc Natl Acad Sci USA 97 (26): 14028-14029
Sommer S, Wehner R. 2012. Leg allometry in ants: Extreme longleggedness in thermophilic species. Arthropod Struct Dev 41 (1): 71 7. DOI: 10.1016/j.asd.2011.08.002.

Stieb S, Kelber C, Wehner R, Rössler W. 2011. Antennal-lobe organization in desert ants of the Genus Cataglyphis. Brain Behav Evol 2011, 77: 136-146.

Ward Philip S, 2007. Phylogeny, classification, and species-level taxonomy of ants (Hymenoptera: Formicidae). Zootaxa 1668 (1668): 549-563. DOI: 10.11646/zootaxa.1668.1.26.

Wardle DA, Hyodo F, Bardgett RD, Yeates GW, Nilsson MC. 2011. Long-term aboveground and belowground consequences of redwood ant exclusion in boreal forest. Ecology 92: 645-656. DOI: 10.1890/10-1223.1.

Wolf H, Wittlinger M, Pfeffer SE. 2018. Two distance memories in desert ants-Modes of interaction. PLoS ONE 13 (10): e0204664. DOI: 10.1371/journal.pone.0204664.

You H, Jin H, Khaldi A, Kwak M, Lee T, Khaine I, Jang J, Lee H, Kim I, Ahn T, Song J, Song Y, Khorchani A, Stiti B, Woo S. 2016. Plant diversity in different bioclimatic zones in Tunisia. $\mathrm{J}$ Asia Pac Biodivers 9 (1): 56-62. DOI: 10.1016/j.japb.2016. 01.002 